\title{
PARSIVOLTINISM IN THREE SPECIES OF OSMIA BEES*
}

\author{
By P. F. Torchio and V. J. Tepedino \\ Bee Biology \& Systematics Laboratory, \\ Agricultural Research Service, USDA, \\ Utah State University, UMC 53, \\ Logan, Utah 84322
}

Individuals of most insect species follow a relatively inflexible tempo of immature development and adult emergence that includes a single period of diapause in one generation per year at a specific stage in the life cycle. A few species depart from this pattern in that a small proportion of individuals of an age cohort require an additional year or more to complete development to the adult stage (Waldbauer 1978, Beck 1980). Among bees, for example, there are brief reports of delayed emergence for several species (Davidson 1896, MacSwain 1958, Krombein 1967, Torchio 1975, Parker 1980, Rust 1980) but none of these studies provides quantitative evidence to demonstrate that delayed emergence is an integral part of the life cycle.

In this study we supply quantitative evidence to document patterns of delayed emergence in three species of megachilid bees (Osmia montana Cresson, $O$. californica Cresson, $O$. iridis Cockerell and Titus). Individuals of these species complete development in either one or two years, i.e., the emergence pattern of each age cohort is bimodal. Waldbauer (1978) used the term "type c" to describe bimodal ahd polymodal emergence patterns in which the peaks of emergence of an age cohort occur in different years. Here we introduce the more descriptive term, "parsivoltine", to refer to this phenomenon. "Parsi" is adapted from the Latin pars for part or partial; -voltine, from the Italian volta for time or cycle is used in its usual entomological sense, as generations (cycles) per year.

Our study addresses the following questions: 1) Does the proportion of one- and two-year individuals in a cohort differ between the two years of study and/or between the two sampling sites? 2) Is there an association between sex and time required to complete development? 3) How are one- and two-year forms distributed

*Manuscript received by' the editor September 9, 1982 
between and within individual nests? 4) Are inter-individual differences in the time required to complete development due to environmental factors or to a genetic polymorphism, or both?

The three Osmia species are restricted to the western U.S. where they are sympatric and at least partially synchronic (late springearly summer). Each nests gregariously in pre-existing holes, usually in wood. The biologies of $O$. montana and $O$. californica are summarized by Rust (1974); the biology of $O$. iridis is currently under study (Torchio, unpub.). Briefly, nests of each species are composed of a linear series of cells. Each cell is provided with pollen, nectar and an egg; cells are separated by partitions constructed of macerated leaf material (O. montana, $O$. iridis) or mud mixed with macerated leaf material (O. californica), and nests are plugged with one or more partitions. Osmia montana and $O$. californica are oligoleges of the Compositae; $O$. iridis is restricted to a non-composite host plant.

\section{Methods}

Nests of these Osmia species were obtained from trap blocks placed at two field locations (Torchio 1976). Trap blocks of sugar pine contained 49 drilled holes to accommodate paper soda straws measuring $14.5 \mathrm{~cm}$ long and $7 \mathrm{~mm}$ inside diameter. One hundred nest blocks were placed at each of two study sites during both study years (1979-1980).

The Faust trapping site was located $42 \mathrm{~km}$ south of Logan, Cache Co., Utah at $1800 \mathrm{~m}$ elevation. This location is on a hillside with a $\mathrm{SW}$ exposure and is covered by large stands of mature aspen (Populus tremuloides Michx.) trees surrounded by open, grassland meadows. The Mendon site is located $24 \mathrm{~km}$ west of Logan at $1500 \mathrm{~m}$ elevation on a hillside having a SE exposure. Solid stands of maple (Acer glabrum Torr.) or aspen trees surrounded by open meadows were characteristic of the area.

During both study years, nest blocks were attached individually to standing trees during mid-May prior to Osmia flight and returned to the laboratory in early July where they remained at room illumination and temperature. All nests were dissected in early September; individual cocoons were opened to determine sex ratios of adults (one-year forms) and position of larvae (two-year forms) in nests. Larvae of two-year forms were weighed on an electrobalance $(0.1$ 

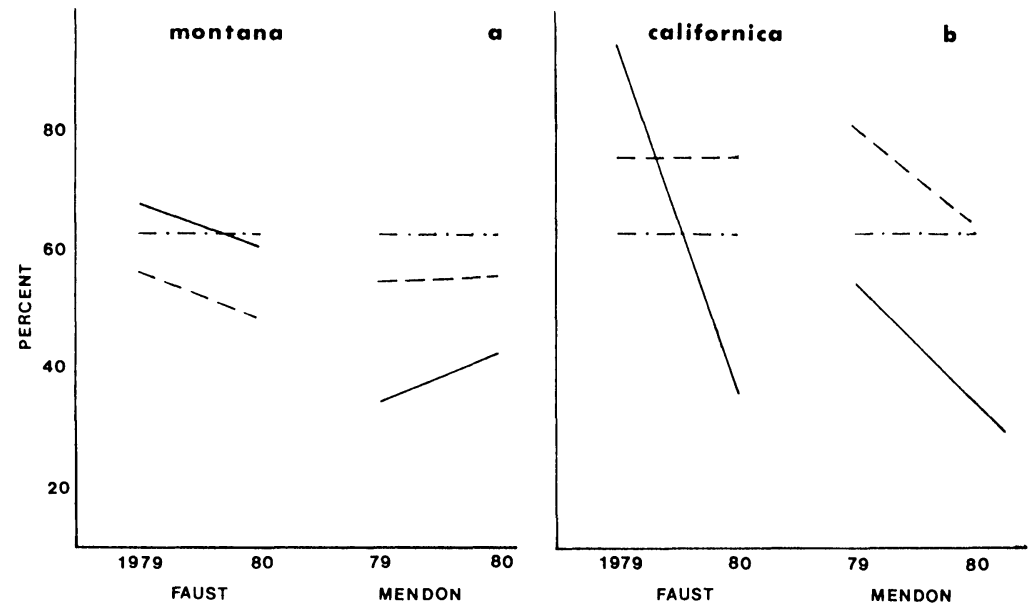

Figure 1. Percent of total offspring of $O$. montana (a) and $O$. californica (b) that were one-year forms (solid lines), and males (dashed line) at two northern Utah sites over two years. Dotted and dashed line represents the expected sex ratio as percent males.

$\mathrm{mg}$ ) and all individuals were then inserted into clear, $\# 000$ gelatin capsules. Capsules were then placed in a constant 4 degrees $\mathrm{C}$ temperature cabinet on September 30 of each study year and transferred to a 26 degrees $C$ temperature cabinet on June 1 of the subsequent year. A photoperiod of OL:24D was maintained throughout these treatments. Capsules containing two-year forms (now adults) were removed from the temperature cabinet on August 30 and reweighed.

\section{RESULTS}

\section{Osmia montana}

Almost 1100 nests were available for examination from the four site-years of sampling (Table 1). Nest utilization was higher in 1979 than in 1980 at both sites, and higher at Faust than at Mendon in both years.

There were differences between sites and years in the proportion of offspring that were one-year forms (Fig. 1a). At Faust a significantly higher proportion of one-year forms was produced in 1979 
than in $1980\left(\mathrm{X}^{2}=19.1, \mathrm{P}<0.001\right)$ whereas at Mendon a significantly higher proportion of one-year cells were produced in 1980 than in $1979\left(\mathrm{X}^{2}=6.3, \mathrm{P}<0.025\right)$. However, the Faust site yielded a significantly greater proportion of one-year cells than did Mendon during both years $\left(1979, \mathrm{X}^{2}=214.1, \mathrm{P} \ll 0.001 ; 1980, \mathrm{X}^{2}=47.4, \mathrm{P}<\right.$ $0.001)$.

An association between sex and the number of years required to complete development was found (Table 1). For all site-years, there were significantly more males than females among one-year forms, and fewer than expected males among two-year forms (Faust 1979, $\mathrm{X}^{2}=9.8, \mathrm{P}<0.005 ; 1980, \mathrm{X}^{2}=22.6, \mathrm{P}<0.001$; Mendon 1979, $\mathrm{X}^{2}=$ $\left.13.9, \mathrm{P}<0.001 ; 1980 \mathrm{X}^{2}=8.8, \mathrm{P}<0.005\right)$. Thus the sex ratio $(\hat{o} /$ o $)$ of one-year forms was always higher than that of two-year forms. However, the sex ratio of one- or two-year forms (taken separately) was not always the same from year to year or from site to site. At Faust the proportion of both one- and two-year males decreased in 1980 (Table 1; one-year forms, $\mathrm{X}^{2}=7.4, \mathrm{P}<0.01$; two-year forms, $\left.\mathrm{X}^{2}=11.9, \mathrm{P}<0.01\right)$ and, as a consequence, the combined sex ratio of offspring declined significantly from $1.3(1979)$ to $0.96(1980)\left(\mathrm{X}^{2}\right.$ $=21.4, \mathrm{P}<0.001)$. Conversely, no such changes occurred at Mendon ( $\mathrm{P}>0.75$ all comparisons).

The incidence of one- and two-year forms appears to be controlled by a genetic polymorphism rather than by the action of environmental variables upon individual offspring. If environmental cues such as photoperiod, thermoperiod, oxygen levels, etc. act either indirectly on the mother or directly on the progeny to determine the developmental fate of offspring, then a consistent pattern of distribution of one- and two-year forms in mixed nests (those containing both one- and two-year forms) should be evident. To examine this possibility we classified mixed nests as follows: 1) oneyear forms in inner cells; two-year forms in outer cells; 2) a reversal of $1 ; 3)$ a double switch, i.e., nests having one-year forms positioned as bottom and top cells with a two-year form between; or, two-year forms sandwiching a one-year form. Only mixed nests that could be categorized with surety were counted; thus, nest totals in Table 2 are fewer than totals listed in Table 1 because some nests were not counted. Such a categorization of nests assumes that all nestmates are siblings. In general this is a valid assumption; supercedure of the nest of one female by another female is an infrequent occurrence. 


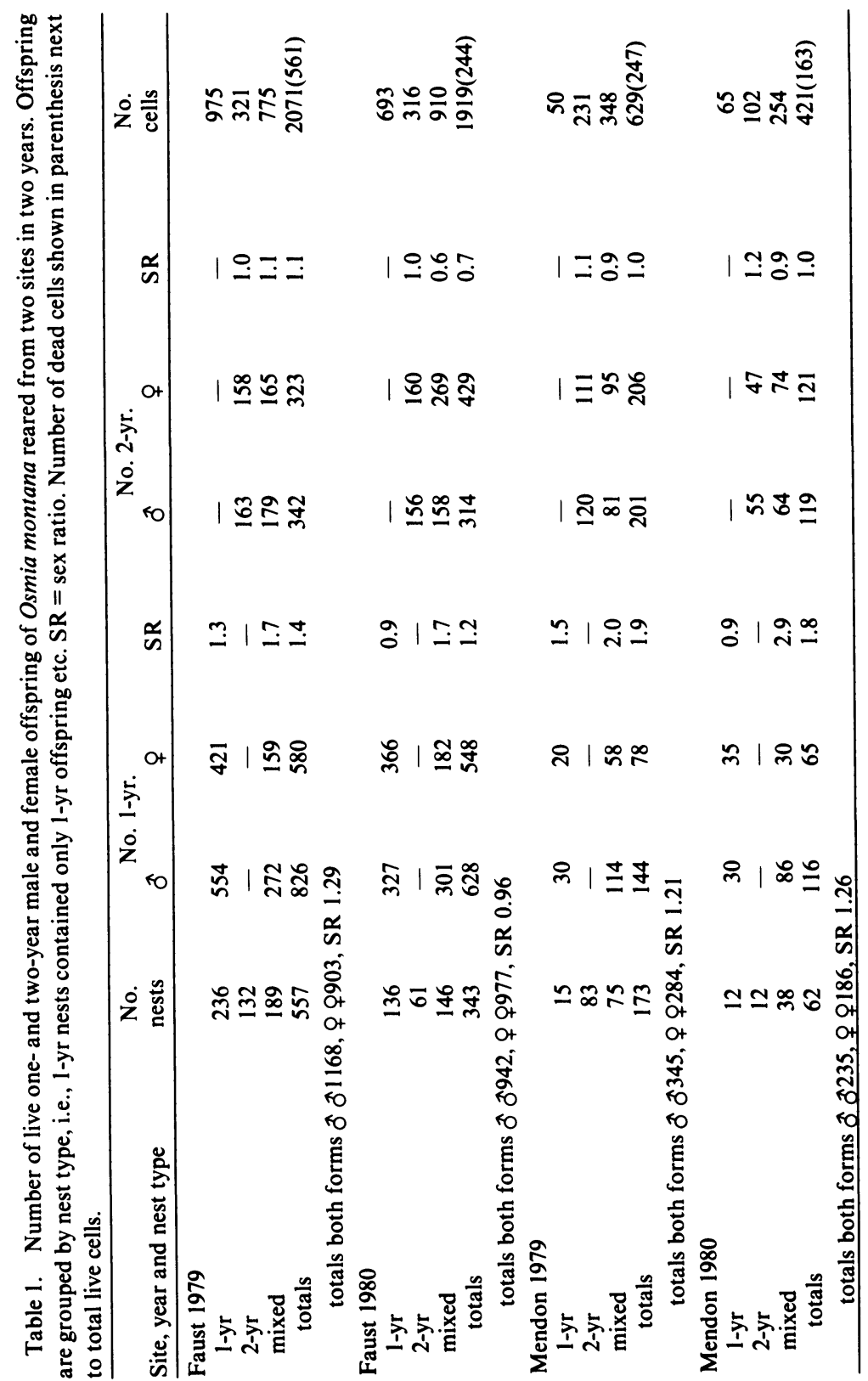


Table 2. Transitions within mixed nests between one- and two-year forms for Osmia montana and californica. Transition from inner one-year forms to outer two year forms $=1-2 \mathrm{yr}$ and similarly for 2-1 yr. Double switch signifies the transitions $1-2-1$ yr or $2-1-2 \mathrm{yr}$.

\begin{tabular}{|c|c|c|c|c|c|c|c|}
\hline & & \multicolumn{3}{|c|}{ Osmia montana } & \multicolumn{3}{|c|}{ Osmia californica } \\
\hline & & $1-2 \mathrm{yr}$ & $2-1 \mathrm{yr}$ & $\begin{array}{l}\text { Double } \\
\text { switch }\end{array}$ & $1-2 \mathrm{yr}$ & $2-1 \mathrm{yr}$ & $\begin{array}{l}\text { Double } \\
\text { switch }\end{array}$ \\
\hline \multirow[t]{2}{*}{ Faust } & 1979 & 22 & 16 & 47 & 0 & 1 & 1 \\
\hline & 1980 & 6 & 31 & 63 & 5 & 4 & 52 \\
\hline Totals & & 28 & 47 & 110 & 5 & 5 & 53 \\
\hline \multirow[t]{2}{*}{ Mendon } & 1979 & 11 & 17 & 32 & 5 & 21 & 12 \\
\hline & 1980 & 3 & 12 & 17 & 3 & 9 & 22 \\
\hline Totals & & 14 & 29 & 49 & 8 & 30 & 34 \\
\hline
\end{tabular}

For example, in a study of marked $O$. lignaria only 5 of 111 nests (same type as used here) made in a greenhouse contained offspring produced by more than one female (Tepedino and Torchio 1982b).

Distribution of one- and two-year forms in mixed nests is summarized in Table 2. Nests with double switches were more numerous than those in the other two categories combined in all site years; transitions from two-year forms in inner cells to one-year forms in outer cells were about twice as common as the reverse situation. Thus, factors such as photo- and thermoperiods, which act on the maternal genotype to induce diapause in the offspring of other species of Hymenoptera (Parker and Tepedino 1982), do not seem to influence the determination of one- or two-year forms in $O$. montana.

The interspersion of one- and two-year forms in mixed nests creates the potential for fratricide. Observations of trap-nests both in field and laboratory demonstrated that one-year forms destroy any two-year larval siblings positioned above them in the nest when they emerge (Torchio, unpub.). We therefore examined the data for mixed nests to determine the number of surviving and "doomed" two-year offspring by sex. The category doomed was assigned to any two-year form with a one-year form between it and the inner limit of the nest. All two-year forms without one-year forms positioned below them were classified as surviving. Our estimates of the percent doomed two-year offspring should be regarded with cau- 
tion. Although all three species nest in pre-existing holes in dead wood, in natural situations it may sometimes be possible for emergent one-year adults to gain egress without destroying their twoyear siblings. For example, if the nest is in a rotting log emergent forms may be able to chew around nestmates. Thus, the estimates given here should be regarded as maximums.

The results of these comparisons (Table 3 ) demonstrate that a large portion of two-year forms was doomed in each site-year (range 40.5-61.3\%). This mortality would be in addition to any losses due to enemies or developmental arrest. It is also interesting to note that in each site-year a significantly lower proportion of two-year females than males would be destroyed by their siblings ( $\mathrm{X}^{2}$ tests, $\mathrm{P}$ $\ll 0.001$ all cases). This is because $O$. montana, like most bees that construct nests in pre-existing holes (including $O$. californica, $O$. iridis), deposit female eggs in cells in the lower reaches of the nest and males in outer cells (Krombein 1967). Thus, the probability that a two-year male larva will be destroyed by an emerging sibling adult is greater than for a two-year female.

Table 3. "Doomed" offspring by sex from mixed nests of Osmia montana and O. californica.

\begin{tabular}{|c|c|c|c|c|c|c|}
\hline \multirow[b]{2}{*}{$\begin{array}{l}\text { Species, } \\
\text { Site, Year }\end{array}$} & \multicolumn{2}{|c|}{ Males } & \multicolumn{2}{|c|}{ Females } & \multicolumn{2}{|c|}{ Totals } \\
\hline & $\mathbf{N}$ & $\begin{array}{c}\% \\
\text { Doomed }\end{array}$ & $\mathrm{N}$ & $\begin{array}{c}\% \\
\text { Doomed } \\
\end{array}$ & $\mathrm{N}$ & $\begin{array}{c}\% \\
\text { Doomed } \\
\end{array}$ \\
\hline \multicolumn{7}{|l|}{ O. montana } \\
\hline Faust 1979 & 179 & 84.9 & 165 & 35.8 & 344 & 61.3 \\
\hline 1980 & 158 & 69.6 & 269 & 23.4 & 427 & 40.5 \\
\hline Totals & 337 & 77.7 & 434 & 28.1 & 771 & 49.8 \\
\hline Mendon 1979 & 81 & 81.5 & 95 & 35.8 & 176 & 56.8 \\
\hline 1980 & 64 & 64.1 & 74 & 24.3 & 138 & 42.8 \\
\hline Totals & 145 & 73.8 & 169 & 30.8 & 314 & 50.6 \\
\hline \multicolumn{7}{|l|}{ O. californica } \\
\hline Faust 1979 & 5 & 40.0 & 2 & 50.0 & 7 & 42.9 \\
\hline 1980 & 207 & 69.1 & 69 & 18.8 & 276 & 56.5 \\
\hline Totals & 212 & 68.4 & 71 & 19.7 & 283 & 56.2 \\
\hline Mendon 1979 & 79 & 46.8 & 40 & 17.5 & 119 & 37.0 \\
\hline 1980 & 49 & 75.5 & 47 & 19.1 & 96 & 47.9 \\
\hline Totals & 128 & 57.8 & 87 & 17.8 & 215 & 41.9 \\
\hline
\end{tabular}




\section{Osmia californica}

Almost 500 nests were recovered in the four-site years of sampling (Table 4). Nest utilization was unchanged at Mendon during both years, but a substantial increase was recorded at Faust from 1979 to 1980.

The proportion of one-year cells declined significantly at both sites from 1979 to 1980 (Fig. 1b, Table 4; Faust $\mathrm{X}^{2}=221.5, \mathrm{P} \ll$ 0.001 ; Mendon $\left.\mathrm{X}^{2}=30.0, \mathrm{P}<0.001\right)$. In agreement with results for $O$. montana, the proportion of one-year forms produced at Faust was significantly higher than that produced at Mendon during both years $\left(1979, \mathrm{X}^{2}=92.5, \mathrm{P} \ll 0.001 ; 1980, \mathrm{X}^{2}=5.7, \mathrm{P}<0.025\right)$.

As with $O$. montana, there was an association between sex and number of years to complete development (Table 4). For all siteyears (except Faust 1979 for which insufficient numbers of two-year forms were available for statistical tests) there was a higher proportion of males among one-year forms than among two-year forms when cells from mixed nests only were considered (Faust 1980, $\mathrm{X}^{2}=$ 4.3, $\mathrm{P}<0.05$; Mendon 1979, $\mathrm{X}^{2}=20.2, \mathrm{P}<0.001 ; 1980, \mathrm{X}^{2}=10.2$, $\mathrm{P}<0.005$ ). When all cells were considered, the sex ratio of one-year forms was always higher than that of two-year forms; but only one of three comparisons was significant (Faust 1980, $\mathrm{X}^{2}=2.4, \mathrm{P}>$ 0.10; Mendon 1979, $\mathrm{X}^{2}=11.8, \mathrm{P}>0.001 ; 1980, \mathrm{X}^{2}=2.0, \mathrm{P}>0.10$ ).

Between-year differences in the proportion of males and females among one- and two-year forms at each site were less evident than for $O$. montana (Table 4). At Mendon the combined sex ratio of offspring declined significantly from $4.2(1979)$ to $1.8(1980)\left(\mathrm{X}^{2}=\right.$ $30.0, \mathrm{P} \ll 0.001)$ but no such change was evident at Faust $\left(\mathrm{X}^{2}=0.0\right.$, $P>0.90)$. The decline in the sex ratio at Mendon was due to a significantly greater proportion of female progeny produced in 1980 for both one-year $\left(\mathrm{X}^{2}=15.5, \mathrm{P}<0.001\right)$ and two-year forms $\left(\mathrm{X}^{2}=\right.$ $7.5, \mathrm{P}>0.01)$. These results are the reverse of those found for $O$. montana.

The distribution of one- and two-year forms within mixed nests were similar to results obtained for $O$. montana (Tables 2, 4). Thus, nests having double switches were most numerous and transitions from one- (inner cells) to two-year forms (outer cells) were intermediate.

As with O. montana, a substantial proportion of two-year forms were "doomed" (range 37.0-56.5\%, Table 3 ) because cells containing one-year forms were often constructed lower in the nest. The 


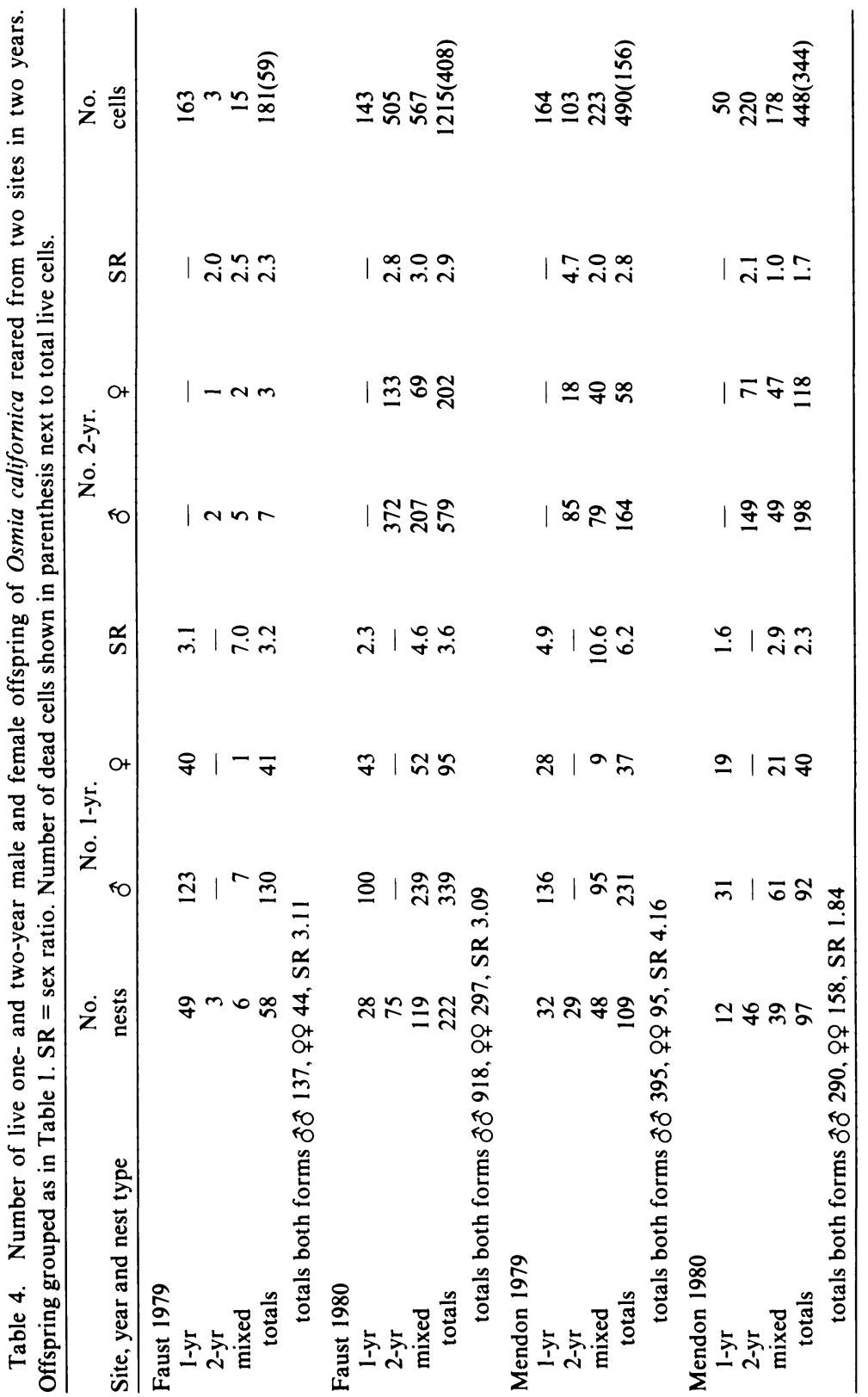


proportion of "doomed" two-year females was also significantly lower than for that of two-year males (Faust 1980, $\mathrm{X}^{2}=53.2, \mathrm{P}<$ 0.001; Mendon 1979, $\mathrm{X}^{2}=9.8, \mathrm{P}<0.005 ; 1980 \mathrm{X}^{2}=30.5, \mathrm{P}<$ 0.001 ).

\section{Osmia iridis}

Trap-nests were utilized by $O$. iridis only in 1979 (Table 5). Of the 83 nests recovered, 54 contained one-year forms exclusively; four nests contained two-year forms; and the remaining 25 nests were mixed. Although relatively few two-year individuals were produced (13.1\%), the proportion of two-year females recovered was greater than that of one-year females (mixed nests, $\mathrm{X}^{2}=16.1, \mathrm{P}<0.001$, total nests, $\mathrm{X}^{2}=9.0, \mathrm{P}<0.005$, both sites combined).

Unlike other Osmia species studied, the predominant transition category of $O$. iridls in mixed nests was from the two-year form (inner cells) to the one-year form (outer cells) 16 of 25 nests). There were relatively few nests with either double switches (5) or with transitions from one-year (inner) to two-year (outer) forms (4).

The tabulation of "doomed" individuals in mixed nests demonstrated that two-year males were at greater risk than two-year females $\left(\mathrm{X}^{2}=6.0, \mathrm{P}<0.025\right)$.

\section{Expected and observed sex ratio:}

We calculated the expected equilibrium sex ratio ( $\hat{\sigma} /$ o $)$ for each species on the basis of male and female live weights (Table 6) as described previously for $O$. lignaria propinqua (Torchio and Tepedino 1980). Two interesting points emerged from this analysis. First, for each species, the expected sex ratio was the same regardless of whether larval or adult weights were used. Second, the expected sex ratios of these three species were very similar to each other and to 0.1 propinqua (Torchio and Tepedino 1980). Apparently the optimal size ratio between females and males is the same for many Osmia species that nest in similar substrates.

When the expected and observed sex ratios were compared, consistent biases emerged: For $O$. montana the observed sex ratio was significantly biased towards females for all site-years $(\mathrm{P}<0.005$ or less, all tests). In contrast, observed sex ratios for both $O$. californica and $O$. iridis were generally biased towards males $(\mathrm{P}<0.001$ or less, all but $O$. californica Mendon 1980). In addition, there was 


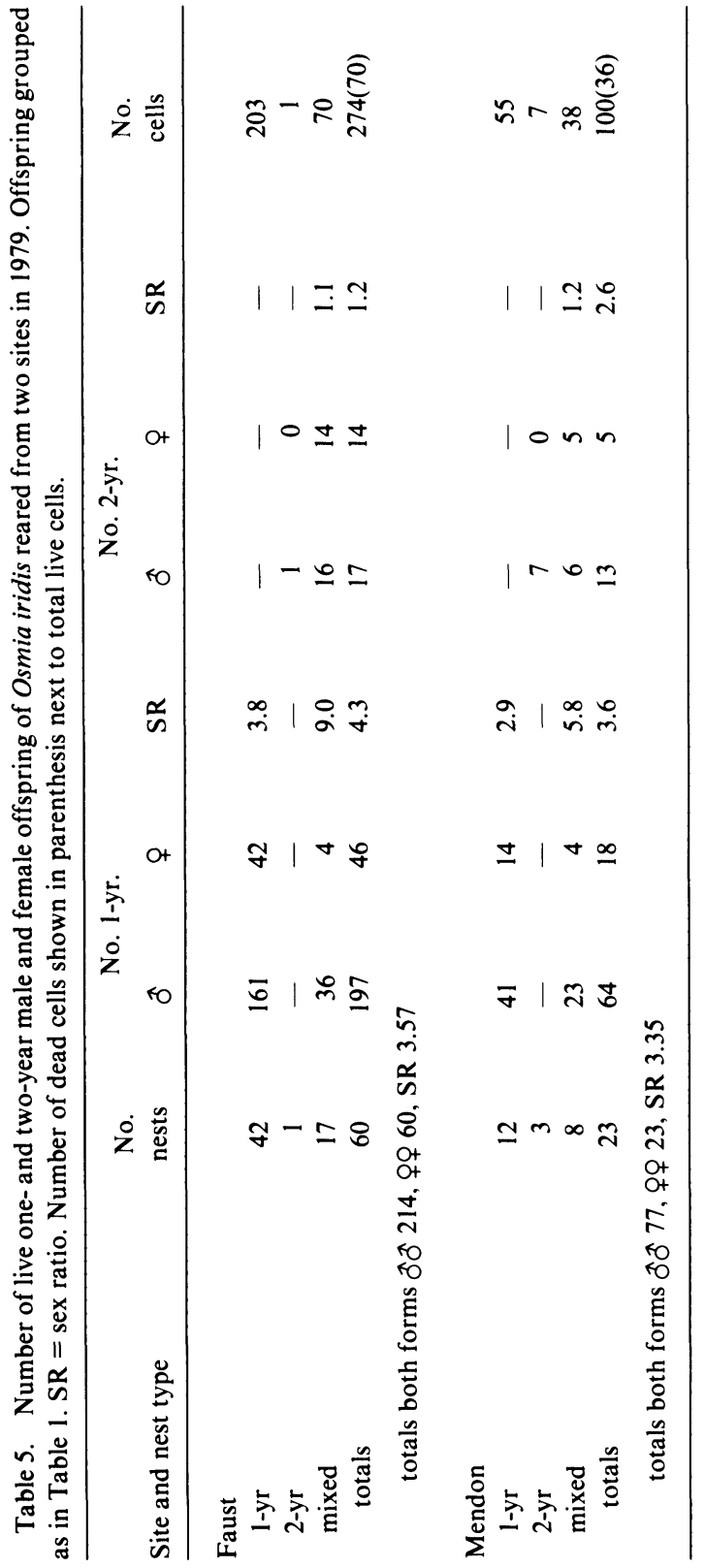


Table 6. Mean fresh weights $(\mathrm{mg})$ of adults and larvae of three species of $O$ smia. Weights for $O$. montana and californica are for two-year forms, those for $O$. iridis for one-year forms. $\mathrm{N}=$ sample size, $\mathrm{ESR}=$ expected sex ratio $(\widehat{\sigma} / q)$.

\begin{tabular}{|c|c|c|c|c|c|c|}
\hline & \multicolumn{2}{|c|}{ Adults } & \multicolumn{2}{|c|}{ larvae } & \multicolumn{2}{|c|}{$\%$ wgt. loss } \\
\hline & $\hat{\theta}$ & 오 & $\widehat{0}$ & 우 & $\widehat{0}$ & 우 \\
\hline \multicolumn{7}{|l|}{ montana } \\
\hline live wgt & 71.9 & 125.3 & 93.1 & 161.7 & 23.0 & 22.6 \\
\hline$\pm \mathrm{SD}$ & 16.1 & 16.9 & 19.2 & 20.3 & 3.0 & 2.1 \\
\hline $\mathbf{N}$ & 21 & 34 & 21 & 34 & 21 & 34 \\
\hline ESR & 1.74 & & 1.74 & & & \\
\hline \multicolumn{7}{|l|}{ californica } \\
\hline live wgt & 73.3 & 121.2 & 94.1 & 156.6 & 22.0 & 22.8 \\
\hline$\pm \mathrm{SD}$ & 14.5 & 19.7 & 18.6 & 21.8 & 4.3 & 3.5 \\
\hline $\mathrm{N}$ & 23 & 16 & 23 & 16 & 23 & 16 \\
\hline ESR & 1.65 & & 1.66 & & & \\
\hline \multicolumn{7}{|l|}{ iridis } \\
\hline live wgt & 38.3 & 66.7 & & & & \\
\hline$\pm \mathrm{SD}$ & 4.9 & 9.5 & & & & \\
\hline $\mathbf{N}$ & 58 & 15 & & & & \\
\hline ESR & 1.74 & & & & & \\
\hline
\end{tabular}

no consistent tendency for observed sex ratios to move towards the equilibrium sex ratio in 1980 for either O. montana or O. californica (Fig. 1).

\section{Discussion}

The data presented above are noteworthy for several reasons. First, these three species provide the best documented examples of parsivoltine emergence patterns in bees. Indeed, among Hymenoptera, detailed examples of parsivoltinism are available only for diprionid sawflies (Prebble 1941, Griffiths 1959, Sullivan and Wallace 1967, Wallace and Sullivan 1974). Previous reports of such emergence patterns in bees have been based on small sample sizes (Dianthidium pudicum consimile (Ashmead) (Davidson 1896), Melissodes robustior Cockerell (MacSwain 1958), Prochelostoma philadelphi (Robertson) (Krombein 1967), Perdita nuda Cockerell, Sphecodes sp. (Torchio 1975), Osmia marginipennis Cresson (Parker 1980), and Hoplitis biscutellae (Cockerell) (Rust 1980) ). 
A second point of interest is that two-year forms of all three species undergo two periods of diapause (once as post-defacating larvae during the first winter, and again as adults over the second winter) whereas one-year forms diapause only as adults. For most other insect species, diapause is stage specific and occurs only once in the life cycle (Beck 1980); there are a few reports of nonhymenopterous insect species that enter diapause in more than one stage (e.g., Harvey 1967, Lounibos and Bradshaw 1975). The physiological mechanisms which enable species to undergo two discrete periods of diapause are unknown (Chippendale 1977, Waldbauer 1978).

A third unusual result of this study is the relatively large proportion of individuals in each age cohort which were two-year forms (Fig. 1). When data for live offspring were combined for all siteyears by species, $41 \%$ of all $O$. montana, $57 \%$ of all $O$. californica and $13 \%$ of all $O$. iridis required two years to complete development. In contrast, the percentage of individuals requiring prolonged periods to complete emergence in most other species with parsivoltine emergence patterns is low (Powell 1974, Waldbauer 1978, Shapiro 1979, Tauber and Tauber 1981).

A potential explanation for the high proportion of two-year forms among these species has been provided by Cohen (1966, 1968). In his treatment of optimal reproductive strategies, Cohen noted that when weather and/or resources exhibit large year to year fluctuations and, as a result, the year to year variance in reproductive success is also large, it would be adaptive for organisms to produce offspring types that differed in the time required to reach maturity. By this means, the effects of years unfavorable to reproduction would not fall upon all members of an age cohort (See also Powell 1974, Hedrick et al. 1976, Waldbauer 1978, Shapiro 1979, Real 1980, Tauber and Tauber 1981). Cohen $(1966,1968)$ also hypothesized that variance in reproductive success should be positively associated with the proportion of offspring that require an extra year (or more) to complete development; and that, as the viability of two-year forms decreased relative to one-year forms, the proportion of two-year forms in the population should also decrease. Thus, Cohen's theoretical results suggest that the high proportion of two-year forms in these Osmia species may be due to 
substantial temporal heterogeneity in the environment and that viability of two-year forms is about the same as that of one-year forms. In addition, the data suggest that there may be differences among these species in the way a heterogeneous environment is experienced. The percentage of two-year forms appears to be higher for $O$. montana and $O$. californica than for $O$. iridis (Fig. 1), and this suggests that variance in reproductive success is lower for $O$. iridis than for the other species.

Although there are no data available to directly address these predictions, trap-nesting returns from northern Utah over the past 10 years (Torchio, unpub.) suggest that $O$. montana and $O$. californica populations are much more stable than are those of $O$. iridis. The latter species is only occasionally abundant and, more frequently, is totally absent from trap-nests. Conversely, trap-nest returns for $O$. montana and $O$. californica fluctuate within much narrower limits. Thus, the data available to us do not support Cohen's $(1966,1968)$ predictions.

Another characteristic expressed by these and other species that does not seem to conform to Cohen's $(1966,1968)$ predictions is the relative viability of one- and two-year forms. For example, Sullivan and Wallace (1967) reported that mortality increased and fecundity decreased with prolonged diapause in the sawfly, Neodiprion sertifer (Geoff.). Although we were unable to compare the mortality rate of one- and two-year forms because it was impossible to assign immature deaths in the first year to either category, it seems clear that mortality of two-year forms must be higher than that for oneyear forms because some of the former will be destroyed when the latter exit the nests in the first year (Table 3). Thus Cohen's requirement that viability of one- and two-year forms be equal seems not to be satisfied. In this regard, the advantage of producing a greater proportion of two-year females than two-year males may simply be a mechanism to reduce mortality levels of two-year forms because females almost always occur in the inner cells of the nest where mortality due to emergence of one-year forms is minimal. Thus some degree of linkage between sex and developmental time in such a system would be selected for. Without linkage, siblingeffected mortality on two-year forms would be even higher.

Despite the apparent lack of agreement between the data and the predictions of Cohen $(1966,1968)$, the between year variation in 
proportion of one- and two-year forms within sites for each species (Fig. 1) suggests that the relative fitness of these forms is determined by environmental conditions. What these conditions are and how they interact with the genotypes to maintain a balanced polymorphism (if indeed it is balanced) remains to be studied.

An interesting ramification of varying selective pressures upon one- and two-year forms is the indirect effect upon the sex ratio of the population. Elsewhere, we (Tepedino and Torchio 1982a) have suggested that data from a long-term field study of $O$. lignaria propinqua Cresson (a univoltine species) supports Fisher's (1958) theory of an equilibrium sex ratio. In the three species studied here, however, it appears that any approach toward equilibrium sex ratio values is dependent upon constraints imposed by selection for parsivoltinism. For example, since there is an association between the two-year form and the female sex, an increase in the relative fitness of two-year forms in any year could divert the population away from equilibrium and towards a female bias in subsequent years. The potential for such diversion should depend on the genetic system responsible for the polymorphism. However, the absence of any consistent tendency for population sex ratios of these species to move towards equilibrium (Fig. 1) suggests that this may be a real phenomenon.

\section{SUMMARY}

Offspring from nests constructed in wooden domiciles by three non-social species of Osmia bees at two sites in northern Utah displayed differences in the time required to complete development to the adult stage. Some members of each age cohort emerged in the following year, but a substantial proportion required two years to complete development. We propose the term "parsivoltine" to describe such emergence patterns.

There were differences in the proportion of one-year forms, both between years, within sites and between sites, within years for each species. The factors influencing these changes are unclear at present. The distribution of one-year and two-year individuals within nests suggests that environmental factors alone do not act on either the female parent or on her offspring to determine the developmental fate of the offspring. Many nests contained both one- and two-year 
forms in unpatterned linear arrangements. All three species appear to be genetically polymorphic for the time necessary to complete development.

There was an association between sex and time required to complete development. Two-year forms were more frequently female than male and one-year forms were more frequently male than female. Female offspring are also typically placed in the innermost cells of the nest. In these linear nests, if a two-year form occurs between the nest exit and a one-year form, then the latter will frequently destroy the former to gain egress from the nest. Thus, this association between sex and developmental time may act to lower sib caused mortality.

In addition, the association between sex and developmental time may constrain an approach to the equilibrium sex ratio because of selection for a particular developmental form.

Although spatiotemporal heterogeneity of weather and/or resources has frequently been offered as an explanation for such developmental polymorphisms, it is by no means clear that this is the case for these species of Osmia. The high proportion of two-year forms, and the differences between developmental forms in mortality, and perhaps fecundity as well, do not fit the profile which is typically offered for parsivoltine species.

\section{ACKNOWLEDGMENTS}

We thank Glen Trostle, Mary Klomps, Pauline Anderson, Charlene Roth, and Barbara Becker for their unselfish efforts in preparing nest blocks, dissections of nests, and weighing bees; and Drs. S. D. Beck (Univ. of Wisconsin), Jerome Rozen, Jr. (Amer. Mus. Nat. Hist.), and C. A. and M. J. Tauber (Cornell Univ.) for their helpful comments on the manuscript.

BECK, S. D.

\section{Literature Cited}

1980. Insect Photoperiodism. Academic Press, Second Ed., New York. 387 pp. Chippendale, G. M.

1977. Hormonal regulation of larval diapause. Annu. Rev. Entomol. 22:121-138.

COHEN, D.

1966. Optimizing reproduction in a randomly varying environment. J. Theor.

Biol. 12:119-129. 
1968. A general model of optimal reproduction in a randomly varying environment. J. Ecol. 56:219-228.

Davidson, A.

1896. Nesting habits on Anthidium consimile. Entomol. News 7:22-26.

FISHER, R. A.

1958. The Genetical Theory of Natural Selection. Dover Publ., Second Rev. Ed. New York. 291 pp.

GRIFFITHS, K. J.

1959. Observations of the European pine sawfly, Neodiprion sertifer (Geoff.), and its parasites in southern Ontario. Can. Entomol. 91:501-512.

HARVEY, G. T.

1967. On coniferous species of Choristoneura in North America. 5. Second diapause as a species character Can. Entomol. 99:486-503.

Hedrick, P. W., M. E. Ginevan, and E. P. Ewing

1976. Genetic polymorphism in heterogeneous environments. Annu. Rev. Ecol. Syst. 7:1-32.

KROMBEIN, K. V.

1967. Trap-nesting Wasps and Bees: Life Histories, Nests and Associates. Smithsonian Press, Washington, D. C. 570 pp.

Lounibos, L. P., and W. E. BradshaW

1975. A second diapause in Wyeomyia smithii: seasonal incidence and maintenance by photoperiod. Can. J. Zool. 53:215-221.

MacSwain, J. W.

1958. Longevity of some anthophorid bee larvae (Hymenoptera: Apoidea). Pan-Pac. Entomol. 34:40.

PARKer, F. D.

1980. Nests of Osmia marginipennis Cresson with a description of the female (Hymenoptera: Megachilidae). Pan-Pac. Entomol. 56:38-42.

Parker, F. D. AND V. J. TePedino

1982. Maternal influence in diapause in the alfalfa leafcutting bee. Ann. Entomol. Soc. Amer. 75:407-410.

Powell, J. A.

1974. Occurrence of prolonged diapause in ethmiid moths. Pan-Pac. Entomol. 50:220-225.

Prebble, M. L.

1941. The diapause and related phenomena in Gilpinia polytama (Hartig). V. Diapause in relation to epidemiology. Can. J. Res. 19:437-454.

REAL, L. A.

1980. Fitness, uncertainty, and the role of diversification in evolution and behavior. Am. Nat. 115:623-638.

Rust, R. W..

1974. The systematics and biology of the genus Osmia, subgenera Osmia, Chalcosmia, and Cephalosmia (Hymenoptera: Megachilidae). Wasmann J. Biol. 32:1-93.

1980. Nesting biology of Hoplitis biscutellae (Cockerell) (Hymenoptera: Megachilidae). Entomol. News 91:105-109. 
ShaPIRo, A. M.

1979. The phenology of Pieris napi microstriata (Lepidoptera: Pieridae) during and after the 1975-1977 California drought, and its evolutionary significance. Psyche 86:1-10.

Sullivan, C. R., and D. R. Wallace.

1967. Interaction of temperature and photoperiod in the induction of prolonged diapause in Neodiprion sertifer. Can. Entomol. 99:834-850.

TAuber, C. A., AND M. J. TAuber.

1981. Insect seasonal cycles: Genetics and evolution. Annu. Rev. Ecol. Syst. 12:281-308.

TEPEdino, V. J., AND P. F. TORChio.

1982a. Temporal variability in the sex ratio of a non-social bee, Osmia lignaria propinqua Cresson. Extrinsic determination or the tracking of an optimum? Oikos 38:177-182.

1982b. Phenotypic variability in nesting success among Osmia lignaria propin$q u a$ females in a glasshouse environment (Hymenoptera: Megachilidae). Ecol. Entomol. 7:453-462.

TORCHIO, P. F.

1975. The biology of Perdita nuda and descriptions of its immature forms and those of its Sphecodes parasite (Hymenoptera: Apoidea). J. Kansas Entomol. Soc. 48:257-279.

1976. Use of Osmia lignaria Say (Hymenoptera: Apoidea, Megachilidae) as a pollinator in an apple and prune orchard. J. Kans. Entomol. Soc. 49:475-482.

TORChio, P. F., AND V. J. TePEDino.

1980. Sex ratio, body size and seasonality in a solitary bee, Osmia lignaria propinqua Cresson (Hymenoptera: Megachilidae). Evolution 34: 993-1003.

WALDBAUER, G. P.

1978. Phenological adaptation and the polymodal emergence patterns of insects, pp. 127-144. In Evolution of Insect Migration and Diapause. H. Dingle (ed.) Springer-Verlag, New York.

Wallace, D. R., AND C. R. Sullivan.

1974. Photoperiodism in the early balsam strain of the Neodiprion abietis complex (Hymenoptera: Diprionidae). Can. J. Zool. 52:507-513. 

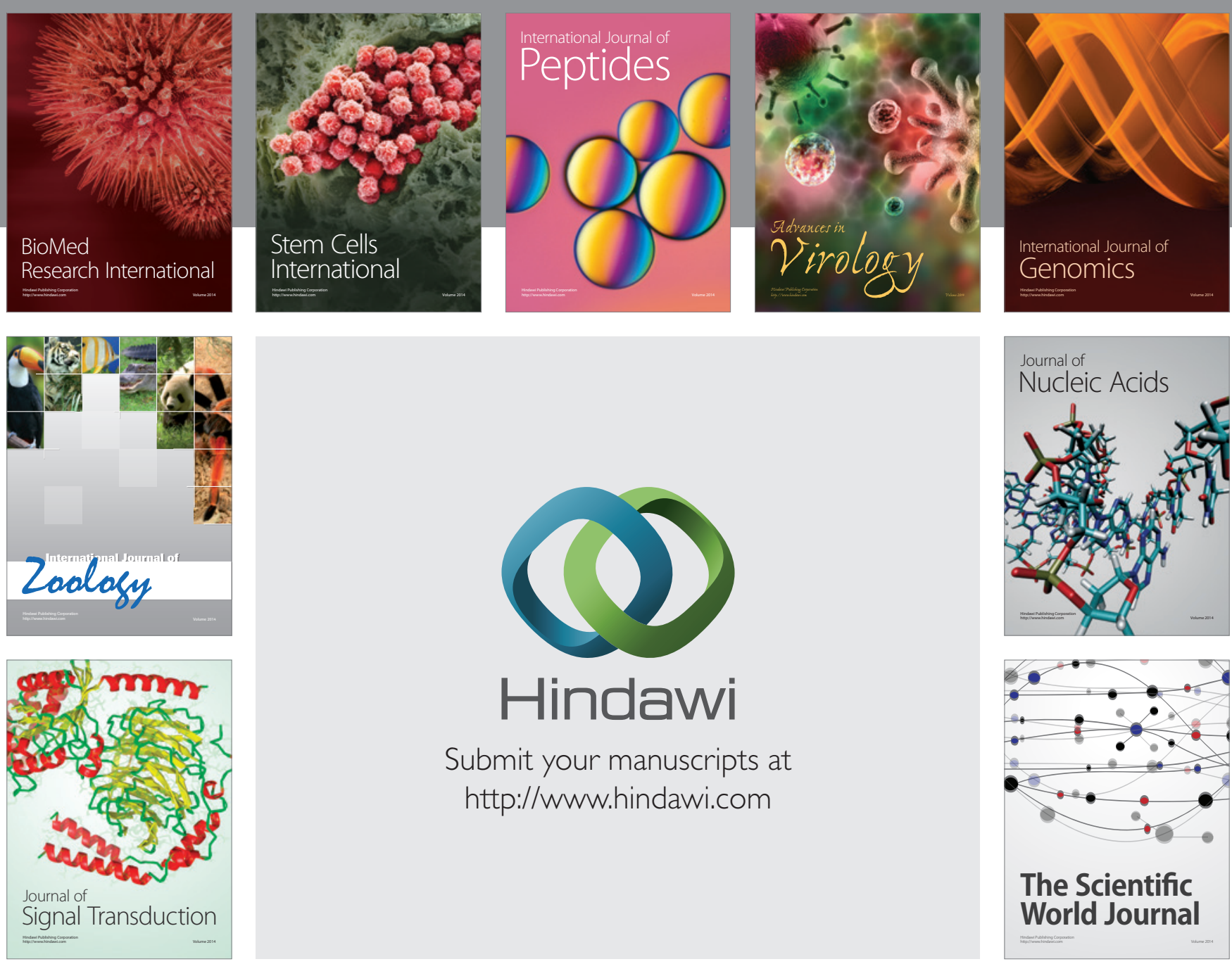

Submit your manuscripts at

http://www.hindawi.com
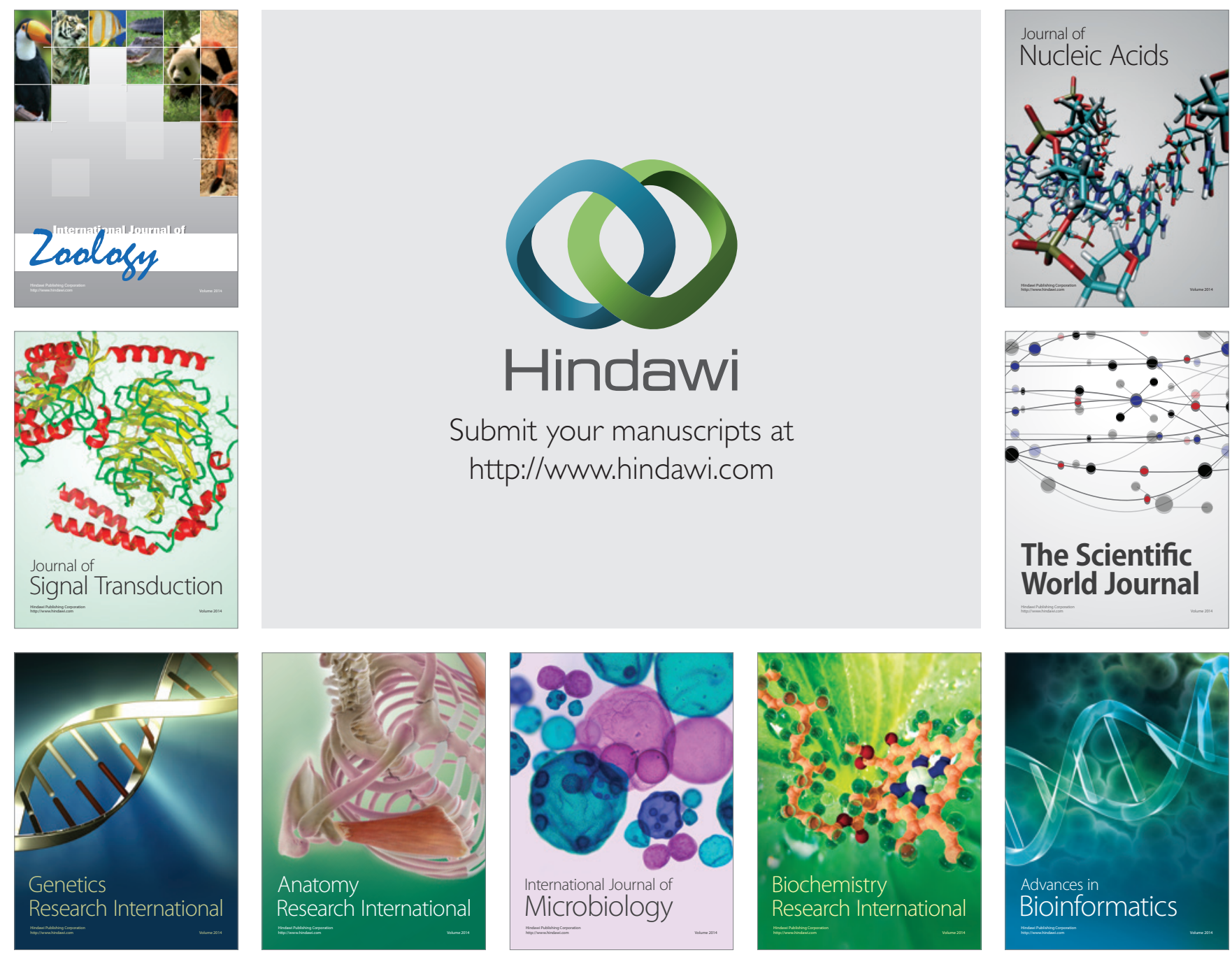

The Scientific World Journal
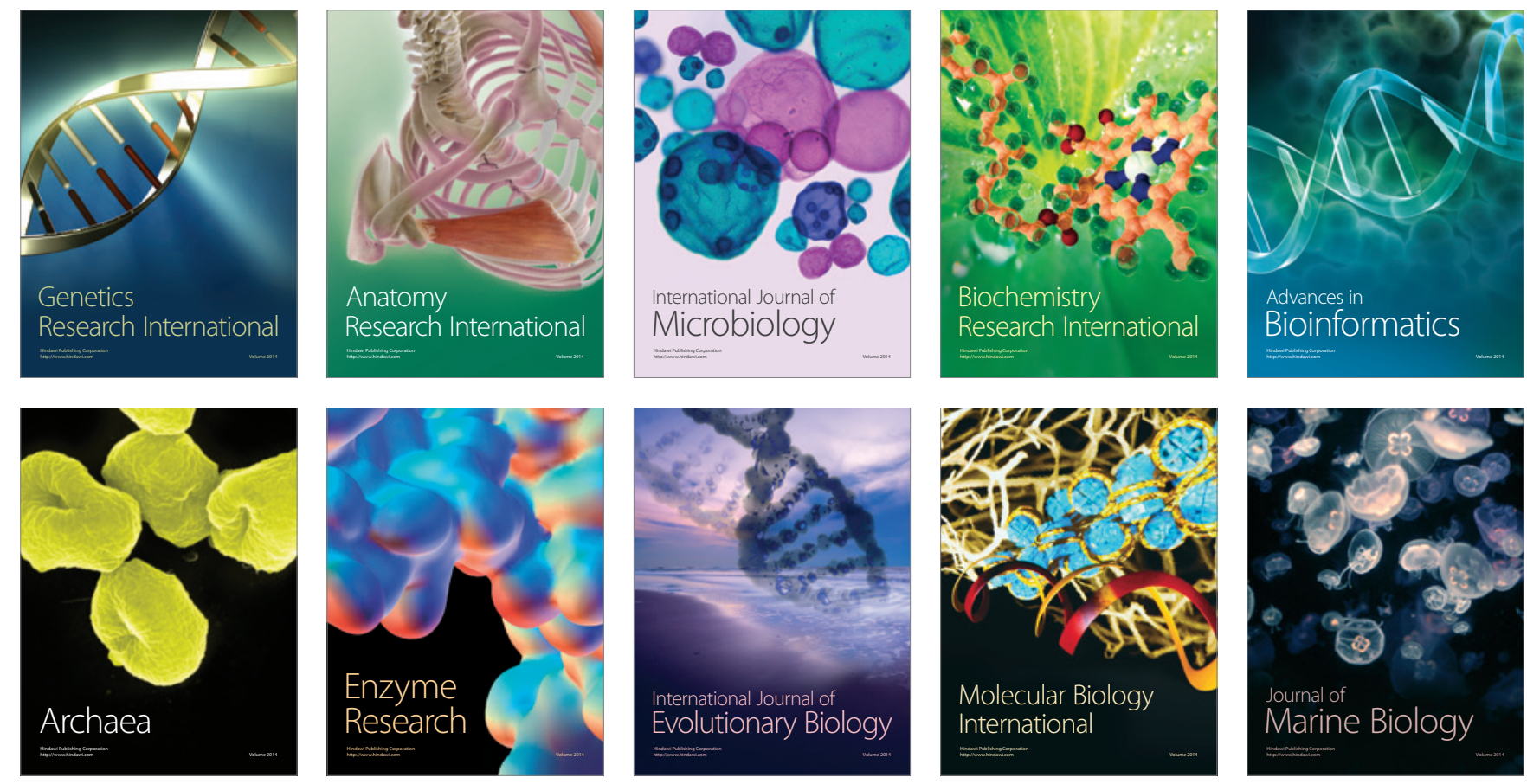